Association for Information Systems AIS Electronic Library (AISeL)

December 2002

\title{
Communicative Practices in Online Communication: a case of agreeing to disagree
}

Geoffrey Greenfield

Griffith University

John Campbell

Griffith University

Follow this and additional works at: http://aisel.aisnet.org/acis2002

\section{Recommended Citation}

Greenfield, Geoffrey and Campbell, John, "Communicative Practices in Online Communication: a case of agreeing to disagree" (2002). ACIS 2002 Proceedings. 17.

http://aisel.aisnet.org/acis2002/17

This material is brought to you by the Australasian (ACIS) at AIS Electronic Library (AISeL). It has been accepted for inclusion in ACIS 2002

Proceedings by an authorized administrator of AIS Electronic Library (AISeL). For more information, please contact elibrary@aisnet.org. 


\title{
Communicative Practices in Online Communication: a case of agreeing to disagree
}

\author{
Geoffrey Greenfield \\ John Campbell \\ School of Management \\ Griffith University \\ g.greenfield@mailbox.gu.edu.au
}

\begin{abstract}
Online communities have evolved beyond the realm of social phenomenon to become important knowledge-sharing media with real economic consequences. However, the sharing of knowledge and the communication of meaning through Internet technology presents many difficulties. This is particularly important in the realm of online finance forums where market sensitive information and disinformation is regularly disseminated about exchange traded stocks. This paper analyses the communicative practices of a group of investors and members of an online community of interest.
\end{abstract}

\section{Keywords}

Finance forum, communicative practices, computer-mediated communication

\section{INTRODUCTION AND BACKGROUND}

Reingold (1995:5) described virtual communities as "social aggregations that emerge from the [Inter]net when enough people carry on those public discussions long enough, with sufficient human feeling, to form webs of personal relationships in cyberspace". Within these virtual communities people are sharing information, asking questions, forming groups and carrying on discussions much as they might in the physical world. However, the voluminous and persistent nature of information created in this medium requires a greater understanding of how individuals make sense of what they read and see. Seligman (2000) argues that individuals make sense through a process of taking action, understanding the effects of the action and incorporating their understanding into a mental model to guide further action. This 'making of sense' (Weick, 1995) has also been described as the reciprocal interaction of information seeking, meaning ascription, and action (Thomas et al., 1993).

In the less-personal computer-mediated communication (CMC) environment, individuals may sometimes use the computer as a buffer between themselves and others (Baruch, 2001). Cecez-Kecmanovic (2001) argues that the underlying conflicts and contradictions, hidden structures and mechanisms that influence these communication environments are revealed through critical information system research by uncovering attempts to misuse $\mathrm{CMC}$ environments to deceive, manipulate, exploit, dominate and disempower other virtual community members.

Previous critical social theory research into computer-mediated communication has studied learning environments in higher education (Treleaven et al., 2000; Cecez-Kecmanovic and Webb, 2000). Through the application of a Communicative Model of Collaborative Learning, Treleaven et al. (2000) attempt to make sense of online discourse and to develop an understanding of communicative acts, what they produce in particular contexts and how they affect knowledge co-creation within a virtual community. It is how CMC supports humans in making sense of the information from and the formation of knowledge within a virtual environment that this paper will address.

The community examined in this paper consists of participants from an Australian-based online finance forum. Finance forums provide a particularly interesting research context for investigating communicative practices. The overarching objective of most finance forum 
participants is to profit from the trading of stock market securities. As a group, the forum purpose and utility is paradoxical. On one hand, forum members are allies attempting to collaboratively generate strategy and uncover information that might assist them in their mutual aim of achieving monetary gain from trading or investing in financial markets (see Campbell, 2001; Wysocki, 2000). However, these same allies are often also adversaries, taking opposing positions in specific transactions of securities. These forum environments generally challenge the limits of interactions experienced in face-to-face situations. While social forms of communicative distortion can still be practiced, the presence of such distortions is more visible, to the participants. Moreover, a web-mediated collaborative environment is more amenable to the analysis of communicative practices based on the text by-product of the online communication process.

\section{FINANCE FORUM COLLABORATION AS SOCIAL INTERACTION}

Individuals participating in Internet-based finance forums typically pursue the aim of being or becoming successful stock investors or traders. At the same time they portray a particular image of themselves to make an impression on other forum participants and sometimes to manipulate and exert power in relation to others. As a result, their involvement in the communicative practices of forum discourse reflects the aims as well as the strategies they adopt to achieve those aims. For example, a forum participant whose primary goal is ethical investing may adopt a strategy of strictly following forum rules so as to publicly demonstrate a high regard for community values. On the other hand, another participant concerned only with maximising investment returns may not be so pedantic in obeying forum rules or community. Different individual objectives and the consequent strategies used to achieve them, produce different communicative practices that, in turn, contribute to the success of a forum.

Cecez-Kecmanovic and Webb (2000) proposed a formal classification framework that places communicative acts along two dimensions: (1) the dominant action orientation and (2) the knowledge domain. They combined these two constructs to produce a $3 \times 3$ schema which facilitates the analysis of collaboration and knowledge co-creation at both the linguistics acts and the action orientation levels (see also Treleaven et al., 2000).

Their communicative practices model presented in Table 1 integrates the two levels of communicative analysis into a representation describing the knowledge domains of linguistic acts (subject matter; norms and rules; and personal experiences) along one dimension, and the dominant action orientation (knowledge creation; achieving ends and self-presentation) along the other. This model can be used to investigate any linguistic act in terms of what and how it contributes to the construction and maintenance of collaborative processes. Although certain linguistic acts may be of the same type, what is actually produced depends on the individual's action orientation.

The communicative model of collaboration can be used to assess the conditions necessary for the development of the ideal communication environment for Internet finance forums. It can be seen that these conditions are progressively better approximated from the bottom level of the self-presentation orientation towards the top level of the knowledge creation orientation as shown in Table 1. Distortion of communication by an individual orientated to self-presentation may for example involve ignorance of others and over-insistence on personal views and opinions; disregard for the desires and wishes of others; instrumentalisation of trust and relationships among group members; and the relegation of the forum to a platform for personal promotion (Treleaven et al., 2000). The kinds of distortion by individuals oriented to achieving goals include linguistic acts aimed at influencing the opinions and beliefs of others, and maintaining relationships with others to serve their own particular goals, etc. The presence of these communicative distortions usually disrupts collaborative processes and, if persistent and severe, may even cause a complete breakdown of communication on a forum. On the other hand, individuals predominantly oriented to creating and sharing knowledge do so in a cooperative way. Instead they seek to establish mutual understanding and respect for others with different viewpoints. 


\section{RESEARCH CONTEXT}

This study describes how group inertia as embodied in online communicative practice impact on the capacity of an online group to negotiate new meaning from controversial interpretations of group knowledge. Our research considers how one online group interacts in the development of consensual knowledge and the openness of group members to issues that dispute widely accepted "facts" and beliefs. The data set used in our analysis consists of posts relating to a specific mining sector company listed on the Australian Stock Exchange referred to as Company A. These posts were made over a period of 4 weeks between 31 January and 28 February 2001 and were chosen because they involved a reasonably large number of individuals and contained an extensive range of communicative acts that dealt with conflictual interpretations of public information about a single company.

It was in this period that one poster (poster 1) questioned the worth of the stock company $A$ and was pilloried by some (see the appendix). Some contributors validated their support of the stock with information and facts concerning performance to date and the future with the hope to sway poster 1. Others questioned poster 1 on the information that was posted and attempted to clarify issues put forward. While still others just tried to stand out from the crowd through self-representation and promotion.

\begin{tabular}{|c|c|c|c|}
\hline $\begin{array}{l}\text { Knowledge } \\
\text { Domains } \\
\text { orientation to: }\end{array}$ & $\begin{array}{l}\text { Subject matter } \\
\text { (1) }\end{array}$ & $\begin{array}{l}\text { Norms and rules } \\
\text { (2) }\end{array}$ & $\begin{array}{l}\text { Personal } \\
\text { experiences, desires } \\
\text { and feelings } \\
\text { (3) }\end{array}$ \\
\hline $\begin{array}{l}\text { Knowledge } \\
\text { Co-Generation }\end{array}$ & $\begin{array}{l}\text { A1 - Linguistic acts about } \\
\text { content matters raised to } \\
\text { share views and beliefs, } \\
\text { to provide arguments } \\
\text { leading to mutual } \\
\text { understanding and } \\
\text { knowledge creation }\end{array}$ & $\begin{array}{l}\text { A2 - Linguistic acts that } \\
\text { establish norms and } \\
\text { rules regarding } \\
\text { interaction and } \\
\text { collaboration; co- } \\
\text { operative assessment of } \\
\text { legitimacy, social } \\
\text { acceptability and } \\
\text { rightness of individual } \\
\text { behaviour }\end{array}$ & $\begin{array}{l}\text { A3 - Linguistic acts } \\
\text { expressing personal } \\
\text { views and feelings about } \\
\text { communication } \\
\text { processes and other } \\
\text { contributors aimed at } \\
\text { sharing experiences and } \\
\text { increasing mutual } \\
\text { understandings }\end{array}$ \\
\hline Achieving ends & $\begin{array}{l}\text { B1 - Linguistic acts that } \\
\text { raise or dispute claims } \\
\text { and provide arguments } \\
\text { about content matters, } \\
\text { with an intent to frame } \\
\text { attention, influence } \\
\text { others and achieve goals }\end{array}$ & $\begin{array}{l}\text { B2 - Acts of changing or } \\
\text { interpreting norms and } \\
\text { rules about the } \\
\text { interaction process so as } \\
\text { to suit a particular } \\
\text { contributors interest and } \\
\text { goals ( may be at the } \\
\text { expense of others) }\end{array}$ & $\begin{array}{l}\text { B3 - Acts expressing } \\
\text { personal experiences in } \\
\text { a way that influences } \\
\text { other users and } \\
\text { contributors to help } \\
\text { achieve goals (e.g. } \\
\text { Emphasising personal } \\
\text { success) }\end{array}$ \\
\hline $\begin{array}{l}\text { Self-representation } \\
\text { and promotion }\end{array}$ & $\begin{array}{l}\text { C1 - raising or disputing } \\
\text { claims and arguments as } \\
\text { a performance on a } \\
\text { stage that serves } \\
\text { personal promotion } \\
\text { (often neglecting an } \\
\text { ongoing argumentation } \\
\text { process) }\end{array}$ & $\begin{array}{l}\text { C2 - Raising or disputing } \\
\text { claims about norms/ } \\
\text { rules or the violation in } \\
\text { order to attract attention } \\
\text { and establish oneself as } \\
\text { a distinguished } \\
\text { contributor (e.g. a leader, } \\
\text { an authority) }\end{array}$ & $\begin{array}{l}\text { C3 - Linguistic acts } \\
\text { expressing personal } \\
\text { experiences and feelings } \\
\text { that project an } \\
\text { impression of importance } \\
\text { in a group or of a key role } \\
\text { in a situation (e.g. Self- } \\
\text { promotion or domination) }\end{array}$ \\
\hline
\end{tabular}

Source: Trealeven et al. (2000)

Table 1: Communicative Model of Collaboration

Company $A$ holds a small interest (6.23 percent) in the oil and gas sector through company $B$. which, in turn, has a 5.25 percent working interest in company $C$ a resource project in the US State of California. The resource project is located in the San Joaquin Basin of California. Company $C$ has a number of wells at various stages of development with a potential gas reserve of 3.1 trillion cubic feet. As can be seen from Figure 1, for the 12 
months ending October 2001, the volume of shares traded was at its greatest in the period from December 2000 to April 2001, although there were several spikes in the trading volumes at other times within the 12 month period. At the time the forum conversations were collected, there was a large interest in the progress the company was making with its investment in the company $C$ prospect. Figure 1 also shows that there was a period of high volume and high prices that coincided with the period when the data was collected.

A total of 67 forum members contributed 181 individual posts in 57 separate threads during the 29-day study period. Table 2 shows that 31 posts (19\% of the total) were single posts that were not replied to and 82 posts (49\% of the total) were located in threads of less than 4 posts in length. Of the $51 \%$, of 6 or greater posts, one thread contained 39 posts and accounted for $15 \%$ of the total posts.

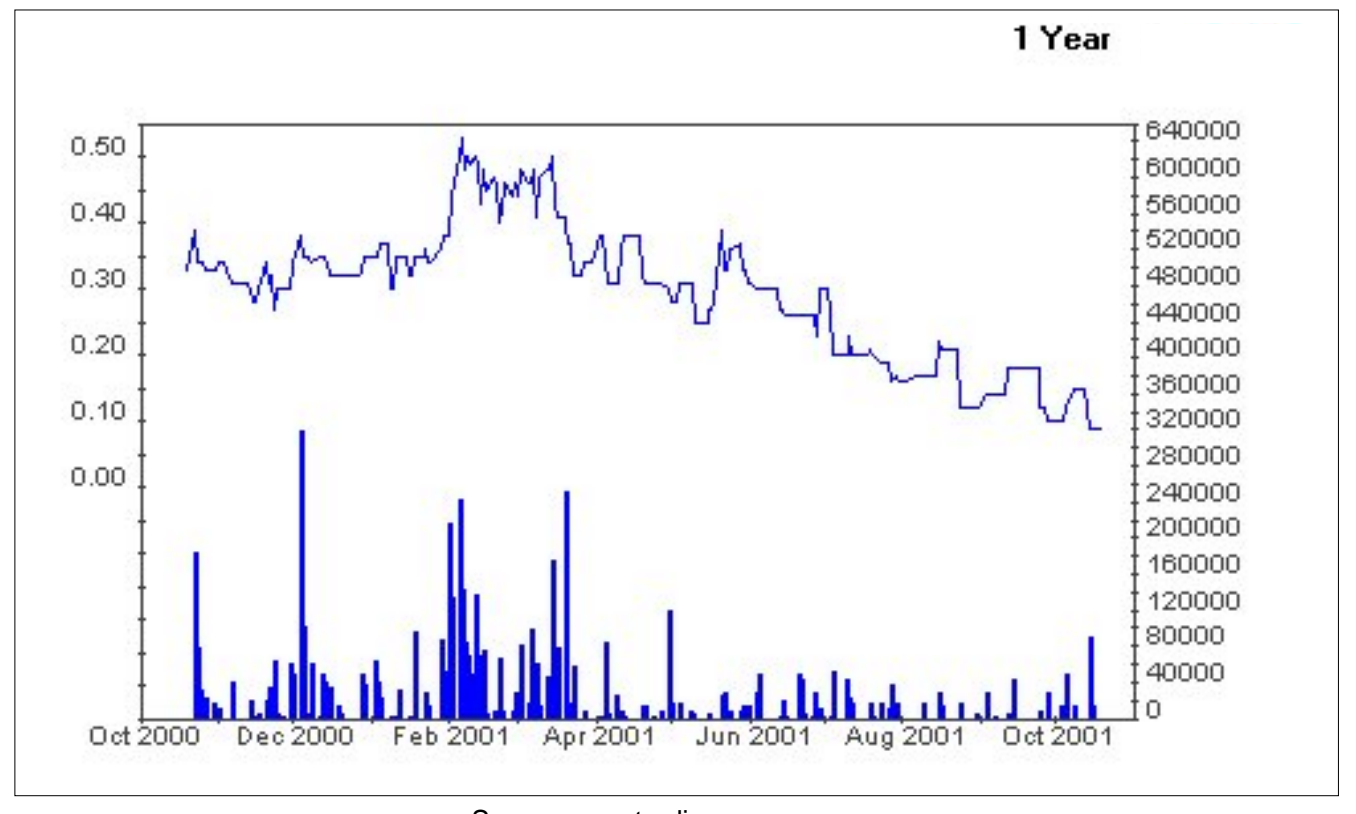

Source www.tradingroom.com.au

Figure 1: Company A daily price and volume chart Oct 2000 to Oct 2001

\begin{tabular}{r|r|r|r|r}
\hline $\begin{array}{l}\text { Number of posts } \\
\text { in thread }\end{array}$ & $\begin{array}{l}\text { Number of } \\
\text { separate threads }\end{array}$ & $\begin{array}{l}\text { Total number of } \\
\text { posts }\end{array}$ & \multicolumn{2}{l}{$\begin{array}{l}\text { Percentage of total } \\
\text { posts }\end{array}$} \\
\hline 1 & 31 & 31 & $19 \%$ \\
2 & 6 & 12 & $7 \%$ \\
3 & 9 & 27 & $16 \%$ \\
4 & 3 & 12 & $7 \%$ \\
5 & 0 & 0 & $0 \%$ \\
6 & 1 & 6 & $4 \%$ \\
7 & 1 & 7 & $4 \%$ \\
8 & 2 & 16 & $10 \%$ \\
9 & 1 & 9 & $5 \%$ \\
10 & 0 & 0 & $0 \%$ \\
11 & 2 & 22 & $13 \%$ \\
$12-38$ & 0 & 0 & $0 \%$ \\
\hline 39 & 1 & 39 & $15 \%$ \\
\hline & 57 & 181 & \\
\hline
\end{tabular}

Table 2: Details of postings in threads 
The text of each post was coded and analysed using the Communicative Model of Collaboration. Table 3 provides examples of each of the elements of the coding system to illustrate the differences in the communication acts within the analysis of data.

\begin{tabular}{|c|c|}
\hline Coding Scheme & Example of messages coded \\
\hline $\begin{array}{l}\text { A1 - Linguistic acts about content matters raised to } \\
\text { share views and beliefs, to provide arguments } \\
\text { leading to mutual understanding and knowledge } \\
\text { creation }\end{array}$ & $\begin{array}{l}\text { Might be of interest to some, this is by someone called } \\
\text { poster } 2 \text { who is to be found in the TA forum of the } \\
\text { US/Canadian Stockhouse. }\end{array}$ \\
\hline $\begin{array}{l}\text { A2 - Linguistic acts that establish norms and rules } \\
\text { regarding interaction and collaboration; co- } \\
\text { operative assessment of legitimacy, social } \\
\text { acceptability and rightness of individual behaviour }\end{array}$ & $\begin{array}{l}\text {... am quite happy for people to post and tell me what they } \\
\text { know about the stock to persuade me to have a further } \\
\text { look. }\end{array}$ \\
\hline $\begin{array}{l}\text { A3 - Linguistic acts expressing personal views and } \\
\text { feelings about communication processes and other } \\
\text { contributors aimed at sharing experiences and } \\
\text { increasing mutual understandings }\end{array}$ & It took me a while but my guess is due diligence! \\
\hline $\begin{array}{l}\text { B1 - Linguistic acts that raise or dispute claims } \\
\text { and provide arguments about content matters, with } \\
\text { an intent to frame attention, influence others and } \\
\text { achieve goals }\end{array}$ & $\begin{array}{l}\text { Before the company A'ites go into meltdown over their own } \\
\text { hype please pause to reflect... }\end{array}$ \\
\hline $\begin{array}{l}\text { B2 - Acts of changing or interpreting norms and } \\
\text { rules about the interaction process so as to suit a } \\
\text { particular contributors interest and goals ( may be } \\
\text { at the expense of others) }\end{array}$ & $\begin{array}{l}\text { Ho Ho HoHo lose plenty face making self look fool.... } \\
\text { Need be more careful with aim or piddle on own foot when } \\
\text { too busy thinking self plenty smart fellow. }\end{array}$ \\
\hline $\begin{array}{l}\text { B3 - Acts expressing personal experiences in a } \\
\text { way that influences other users and contributors to } \\
\text { help achieve goals (eg. Emphasising personal } \\
\text { success) }\end{array}$ & $\begin{array}{l}\text {...you were not pontificating to the masses, nor did you } \\
\text { seem to be trying to put yourself over as an expert of some } \\
\text { sort }\end{array}$ \\
\hline $\begin{array}{l}\text { C1 - raising or disputing claims and arguments as } \\
\text { a performance on a stage that serves personal } \\
\text { promotion (often neglecting an ongoing } \\
\text { argumentation process) }\end{array}$ & $\begin{array}{l}\text { I hold a great deal of respect for you and up until now have } \\
\text { treated your posts with respect ... What I would like to } \\
\text { know is why do you now come out and bag company A. }\end{array}$ \\
\hline $\begin{array}{l}\text { C2 - Raising or disputing claims about norms/rules } \\
\text { or the violation in order to attract attention and } \\
\text { establish oneself as a distinguished contributor } \\
\text { (eg. a leader, an authority) }\end{array}$ & $\begin{array}{l}\text {...than when you are simply trying to mislead, sorry I mean } \\
\text { inform, readers of this forum }\end{array}$ \\
\hline $\begin{array}{l}\text { C3 - Linguistic acts expressing personal } \\
\text { experiences and feelings that project an } \\
\text { impression of importance in a group or of a key } \\
\text { role in a situation (eg. self-promotion or } \\
\text { domination) }\end{array}$ & $\begin{array}{l}\text {...people around here get their nostrals (sic) all flared up } \\
\text { over nothing really, but imagine that it some how hurts } \\
\text { their hip pocket }\end{array}$ \\
\hline
\end{tabular}

Table 3: Examples of Communicative Model of Collaboration

Table 4 summarises the overall analysis of the 181 contributions. Several posts had more than one classification as the posted message contained more than one orientation. Of the total of 188 score codings, 65 percent were directed towards knowledge co-generation, 32 percent were directed to achieving ends, and six percent were directed to self- 
representation and promotion. When comparing this to the results reported by Treleaven et al. (2000), there is a marked difference in the reported dominant orientation of the contributed posts. In the learning environment of a university, Treleaven et al. (2000) reported that 76 percent of contributions were orientated to knowledge co-generation, compared to 62 percent in this study. However, in our study the 32 percent of contributions that were aimed at achieving ends was nearly 69 percent larger than for the university student forum. The number of contributions where the orientation was to self-representation and promotion was similar in both studies (five percent for Treleaven et al. and six percent for this study).

\begin{tabular}{|c|c|c|c|}
\hline $\begin{array}{l}\text { Dominant } \\
\text { Orientation to }\end{array}$ & $\begin{array}{l}\text { Communicative } \\
\text { Code }\end{array}$ & $\begin{array}{l}\text { Total coded } \\
\text { messages }\end{array}$ & $\begin{array}{l}\% \text { of total } \\
\text { messages }\end{array}$ \\
\hline \multirow{4}{*}{$\begin{array}{l}\text { Knowledge } \\
\text { Co-generation }\end{array}$} & $\mathrm{A} 1$ & 78 & $41 \%$ \\
\hline & A2 & 7 & $4 \%$ \\
\hline & A3 & 32 & $17 \%$ \\
\hline & TOTAL A & 117 & $62 \%$ \\
\hline \multirow{3}{*}{ Achieving Ends } & B1 & 54 & $29 \%$ \\
\hline & B2 & 3 & \\
\hline & TOTAL B & 60 & $32 \%$ \\
\hline \multirow{5}{*}{$\begin{array}{l}\text { Self-Representation and } \\
\text { promotion }\end{array}$} & C1 & 6 & $3 \%$ \\
\hline & C2 & 2 & $1 \%$ \\
\hline & C3 & 13 & $2 \%$ \\
\hline & TOTAL C & 11 & $6 \%$ \\
\hline & TOTALS & 188 & $100 \%$ \\
\hline
\end{tabular}

Table 4: Contributors communicative patterns summary

The dynamism of communicative acts over time is shown in Figure 2. The intensity of the interaction, shown by the number of postings, shows the orientation of each post to knowledge co-generation, achieving ends, and self-representation and promotion. During the study period there were posts that contributed to knowledge co-generation on every day except for one. This desire to contribute to the overall knowledge of the group was punctuated by days when posting orientation changed to a focus of achieving ends. In the period up to the 9 February there were posts every day that were orientated to knowledge co-generation and all, except one day, postings orientated towards achieving ends. There were always a greater number of postings orientated to knowledge. Additionally, only on four of the days was there any orientation in the postings towards self-representation and promotion.

This differed from the period beginning on the 12 February, when the orientation of the postings shifted to a more balanced relationship between knowledge and achieving ends. On the 14 February a greater number of postings were orientated to achieving ends. These periods differed from the earlier period in that more of the contributors orientated their postings at achieving ends, rather than contribute to the knowledge of the discussion.

\section{CONCLUSION}

There was a strong overall focus within the sampled data towards contribution to the subject matter, with a dominant orientation to knowledge co-generation. The study site is an informational site and members willingness and ability to share information is apparent. The sharing of information on the site occurred to varying degrees right across the research period.

It could be seen that when the group felt that their enthusiasm for the stock and the stock itself was questioned, the orientation of the posters changed to one of defence. However, 
the focus of forum conversation quickly returned to knowledge co-generation. This research has shown that in the environment of Internet finance forums conflict can encourage the participation in the conversation and the sharing of knowledge. However, there is a need for future research to further consider the benefits of this type of conflict within the environment of Computer Mediated Communication.

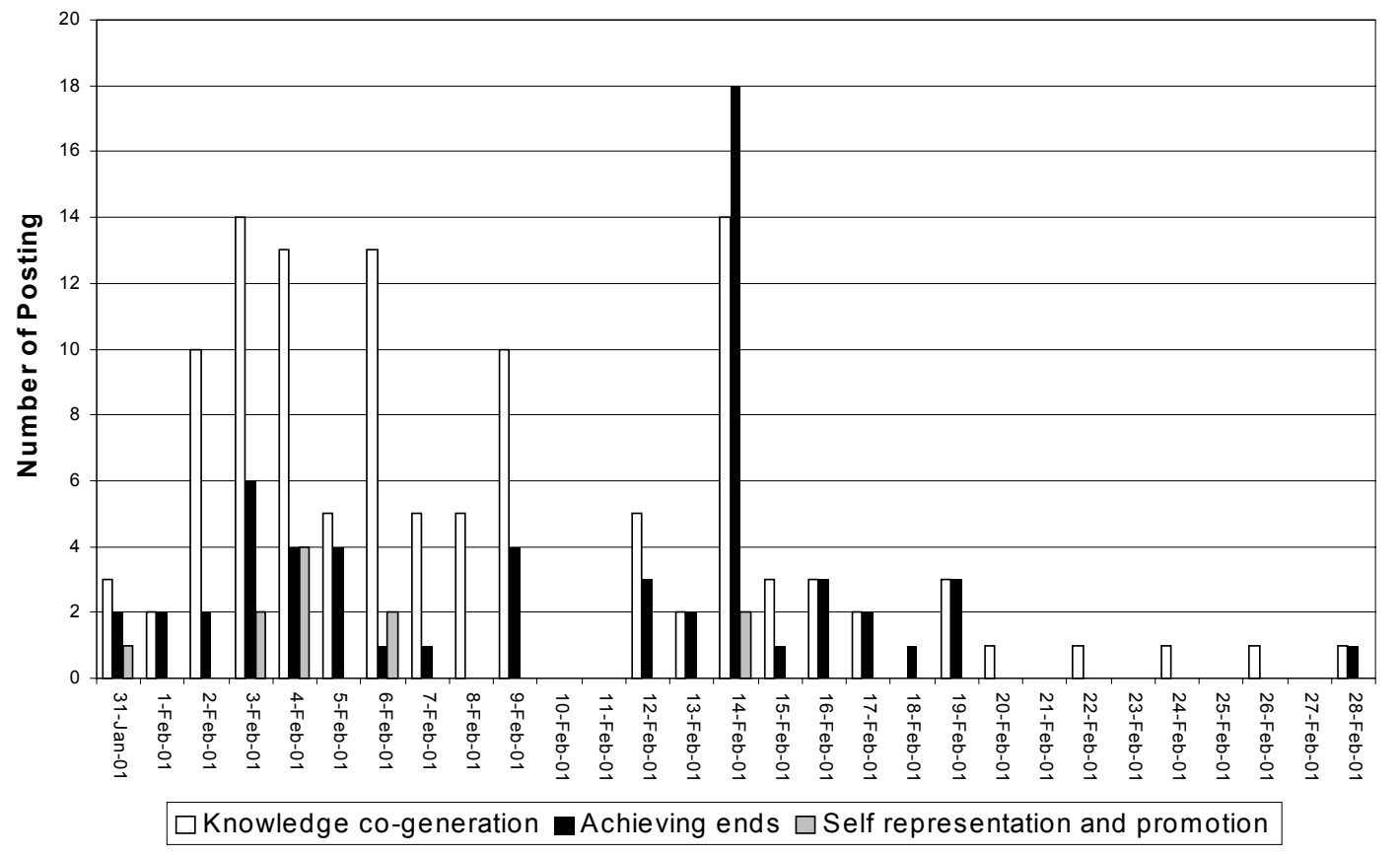

Figure 2: Contributors communicative patterns

\section{REFERENCES}

Baruch Y (2001) The autistic society, Information \& Management, 38, 129-136.

Campbell, J. A. (2001) Internet Finance Forums: Investor Empowerment through CMC or Market Manipulation on a Global Scale? AMSIC 2001 Proceedings of the Seventh Americas Conference on Information Systems, Boston Massachusetts, 3-5 August 2001.

Cecez-Kecmanovic, D (2001) "Doing Critical IS Research: The Question of Methodology", in E. Trauth, (Ed) Qualitative Research in IS: Issues and Trends, Hershey: Idea Group Publishing.

Cecez-Kecmanovic, D. and Webb, C. (2000) Towards a communicative model of collaborative web-mediated learning, Australian Journal of Educational Technology, 16(1), 73 - 85 [Online], Available: http://cleo.murdoch.edu.au/ajet/ajet16/cecezkecmanovic.html [2001- Mar. 28]

Reingold, H. (1995) The Virtual Community, London: Minerva Paperback.

Seligman, L. (2000) Adoption as sensemaking: Toward an adopter-centred process model of IT adoption. International Conference on Information Systems, Brisbane Australia, 1013 December 2000.

Thomas, J., Clark, S. and Gioia, D. (1993) Strategic sensemaking and organizational performance: Linkages among scanning, interpretation and outcomes, Academy of Management Journal, 36(2), 239-270.

Treleaven, L., Cecez-Kecmanovic, D. and Wright, S. (2000) Communicative practices in Web-Mediated Collaborative Learning: A view from within, Conference Proceedings of Working Knowledge: Productive Learning At Work, 10-13 December 2000, UTS, Australia, pp.445-452.

Weick K. (1995) Sensemaking in Organizations, Thousands Oaks, CA: Sage Publications. 
Wellman, B. and Gulia, M. (1999) "Virtual communities as communities", in M. Smith \& P. Kollock (eds.) Communities in cyberspace (pp.167-194). London: Routledge.

Wysocki P. D. (2000) Message boards speak volumes - and volatility, Futures, 29(12), pp. 42-44.

\section{APPENDIX}

A post by the group protagonist with examples of typical responses.

\section{Protagonist:}

I wouldn't get too excited about company A. Nothing in their announcements shows any progress to real revenue creation. In the last quarter they went into a negative cash position. Below their last Cash Flow 2nd Qtr.

\section{Some replies to this post included:}

A week or 2 back you made comment in a post that you did not know why people on $\mathrm{HC}$ took offence at your posts. Very simple. Your post on the subject of company $A$ is an excellent example. You make a derogatory downramping statement about a company it is obvious you have done no $D D$ on whatsoever apart from looking at the last quarters financials. Get your head out of your nether region and put company $A$ in search and just read some of the reports and analysis of the last week.

Positive cash flow for company A could well be a couple of years away with all the wells still to be drilled. But the value of their assets is increasing rapidly.

You first logged on to forum in 7/99, about the same time I arrived here. You know as much about company $A$ as I do, There is no way that anything about company $A$ would or could pass you by, so why act so ignorant now. I hold a great deal of respect for you and up until now have treated your posts with respect, I have even bought some of the shares you recommended in the past. Thank you. I bought the first of my shares in company A early in 99 at .18c. These original shares have now almost tripled in value. What I would like to know is why do you now come out and bag company A. Your statement "I wouldn't get too excited about company A. Nothing in their announcements shows any progress to real revenue creation." What the hell are you on about. YOU KNOW as well as I do company $A$ through and with other companies are sitting on trillions of cubic feet of Gas the first of which goes to market this weekend. If that is not revenue creation you tell me what is.

http://24.42.27.141/returns.html Have another look and this time look at company A. You know exactly what the potential is so I am not going to waste my time going through it just for you. I guess you are one of the fence sitters who have put off buying and now think it is too late to get on board. Don't take out your frustration here by posting misleading information. Buy in and be happy like at least 50 other members of forum are. Just don't peddle your crap here. (By the way trillions is a lot.)

I hope that when you are actually investing in a stock you are a bit more careful than when you are simply trying to mislead, sorry I mean inform, readers of this forum.

I think you have been exposed for what you are. 
Someone who has an opinion on everything, but in truth, knows nothing about anything. My suggestion is simple, you, and any other sceptics, simply place company $A$ on your watch list, and do nothing other than watch company A fly!

Why do you insist on posting negative comments about this stock? Whilst what you say may not necessarily be false, what you don't say is quite misleading. Example: you say "so good test results don't always relate to good performance or money". This statement may well be true but in company A's case we are not talking about test results, we are beyond that, we have a producing well going on line this weekend which will be generating positive cash flow in the vicinity of US\$100,000 per day.

Your comments about company A's cash position are also misleading. Let's have a closer look at that cashflow shall we? The only reason that company A now has a negative cash position is because during the quarter they spent $\$ 168,000$ on equity investments while only raising $\$ 73,000$ from the sale of equity investments. Company A could quite easily sell some of their recently acquired equity investments and have sufficient cash to meet their administration costs. I would be extremely confident in saying that if company $A$ were to sell all of the equity investments that they acquired in the last quarter they would receive considerably more than $\$ 168,000$.

XEN have 4.7 million shares in a publicly listed company called company $B$. Company $B$ is currently trading at C\$1.65 (AUD\$2.00). Therefore at current values company $A$ has $\$ 9.4$ million worth of company $B$ shares alone. This does not include the 2.2 million share purchase warrants which are all presently in the money. I don't think company $A$ is in any real danger of running out of cash in the near future.

The only cash requirement that company $A$ will have in the future will be to fund it's share of future drilling costs. If you forecast total drilling costs for this year to be US\$100,000,000 then company A's portion of this is under US\$1.5million (AUD\$2.7million). This ignores any revenue that will be received from gas sales which will be used to fund further drilling. company A could quite comfortably raise this money by either selling a portion of their equity investments, selling their real estate asset or by conducting a share offering which would have a minor dilutionary effect.

I really can't see company $A$ encountering any problems at all in the future and I have very serious doubts about your motivation for your continued attempts to try and rubbish this stock.

I honestly didn't think investing in XEN could get any better. The whole experience of learning about how they drill for gas, the production process, the relationship between company $A$ and company $B$, the size of company $C$, the intrigue of the Hunt bid, the interaction with all others involved in company $A$, the suspense, the excitement.......it goes on and on. (oh and the profit!)

And then you come along. My friend you are the cherry on the icing on the cake. Please continue to ignore the 'facts'.........eep coming at 'em. l've never enjoyed anything as much as this in years. You are definitely on my Christmas list.

Yours in absolute disbelief!!!! 


\section{COPYRIGHT}

Geoffrey Greenfield and John Campbell (C) 2002. The authors assign to ACIS and educational and non-profit institutions a non-exclusive licence to use this document for personal use and in courses of instruction provided that the article is used in full and this copyright statement is reproduced. The authors also grant a non-exclusive licence to ACIS to publish this document in full in the Conference Papers and Proceedings. Those documents may be published on the World Wide Web, CD-ROM, in printed form, and on mirror sites on the World Wide Web. Any other usage is prohibited without the express permission of the authors. 